\title{
MAGNETITE AND ILMENITE FROM SOME FINNISH ROCKS
}

\author{
Ilmari HaApala and Pentti Ojanperä
}

\begin{abstract}
Haapala, Ilmari and Ojanperä, Pentti 1972: Magnetite and ilmenite from some Finnish rocks. Bull. Geol. Soc. Finland 44, 13-20.

Coexisting accessory magnetite and ilmenite were separated and chemically analysed from five Finnish Precambrian rocks: anorogenic olivine diabase and gabbroanorthosite as well as three metamorphosed Svecofennian quartz diorites. Estimations of equilibration temperatures and oxygen fugacities are made on the basis of the analyses. The microtextures of the Fe-Ti oxides are described. The crystallographic orientation law of ilmenite lamellae in magnetite is verified by $\mathrm{X}$-ray single-crystal technique.
\end{abstract}

Ilmari Haapala and Pentti Ojanperä, Geological Survey of Finland, 02150 Otaniemi, Finland.

\section{Introduction}

In 1955 Buddington, Fahey and Vlisidis suggested that in the $\mathrm{Fe}_{3} \mathrm{O}_{4}-\mathrm{FeTiO}_{3}$ system, where ilmenite is present as independent grains, the $\mathrm{TiO}_{2}$ content of magnetite largely depends on the crystallization temperature. Their study was based on a large number of magnetite analyses from different kinds of rocks. Several authors (e.g. Heier 1956, Marmo 1959, Abdullah and Atherton 1964) have since commented on the study. The experimental studies of Lindsley $(1962,1963)$ produced fundamentally new knowledge concerning the Fe-Ti oxides. He showed that the compositions of titaniferous magnetites (expressed as $\mathrm{Fe}_{3} \mathrm{O}_{4}-\mathrm{Fe}_{2} \mathrm{TiO}_{4}$ solid solutions) and ferrian ilmenites $\left(\mathrm{FeTiO}{ }_{3}-\mathrm{Fe}_{2} \mathrm{O}_{3}\right.$ solid solutions) depend on the temperatures and oxygen fugacities of their formation. In 1964, Buddington and Lindsley published a comprehensive study on $\mathrm{Fe}$ - $\mathrm{Ti}$ oxides and their synthetic equivalents, in which the phase-equilibrium studies of Lindsley were applied to natural minerals. The crystallization (equilibration) temperatures and oxygen fugacities of coexisting pairs of titaniferous magnetite and ilmenite were determined for different kinds of rocks. Since the study of Buddington and Lindsley, analysed magnetite-ilmenite pairs have been used in numerous studies as a geothermometer and oxygen barometer (e.g. Carmichael 1967, a and b). The present paper is an attempt to apply the methods of Buddington and Lindsley to some Finnish Precambrian rocks. 


\section{The samples}

The rock samples for the study of coexisting magnetite and ilmenite pairs were taken from the following localities:

1. Olivine diabase (medium-grained variety), parish of Rauma, Sorkka. Map 1132, coordinates $\mathrm{x}=6785.18, \mathrm{y}=531.80$. Ref. Laitakari 1928, Kahma 1951.

2. Gabbroanorthosite, parish of Mäntyharju. Map 3114, coordinates $\mathrm{x}=6797.47, \mathrm{y}=$ 480.67. Ref. Savolahti 1956 and 1966, Kallio 1967.

3. Quartz diorite, town of Mikkeli. Map 3142, coordinates $\mathrm{x}=6683.80, \mathrm{y}=514.25$.

4. Quartz diorite, parish of Virtasalmi, Litmanen. Map 3231, coordinates $\mathrm{x}=6884.90$, $\mathrm{y}=527.70$. Ref. Hyvärinen 1968.

5. Quartz diorite, parish of Virtasalmi. Map 3231 , coordinates $\mathrm{x}=6882.31, \mathrm{y}=530.51$. Ref. Hyvärinen 1968.

The first two of these rocks are anorogenic, practically unmetamorphosed late Precambrian igneous rocks, the others are metamorphosed Svecofennian deep-seated rocks. In olivine diabase and gabbroanorthosite the Fe-Ti oxides are xenomorphic filling the spaces between other minerals (Fig. 2). Thus, they are formed somewhat later than the other main minerals. Ilmenite occurs both as independent grains and intergrown with magnetite. In the quartz diorites the Fe-Ti oxides are often idiomorphic. They were apparently formed by recrystallization during metamorphism. The mineral associations of the rocks are presented in Table 1.

In addition to the rocks mentioned above, an attempt was also made to separate magnetite and ilmenite from two rapakivi granite varieties (Tarkki granite and Väkkärä granite) from Eurajoki, SW Finland. Though the samples weighed several tens of kilograms, these mineral pairs were not received sufficiently for chemical analysis.
TABLE 1

Mineralogical compositions of the studied rock samples. Determined by the point counting method. Numbering of the specimens in the text

\begin{tabular}{|c|c|c|c|c|c|}
\hline & 1 & $\left.2^{1}\right)$ & 3 & 4 & 5 \\
\hline Plagioclase ..... & 67.1 & 82.0 & 61.9 & 61.7 & 61.3 \\
\hline Pyroxene ....... & 10.1 & 9.5 & - & - & - \\
\hline Olivine ........ & 14.6 & - & - & 一 & 一 \\
\hline Quartz ......... & - & 0.8 & 25.8 & 23.3 & 11.1 \\
\hline Hornblende .... & & $\left.0.4^{2}\right)$ & 3.1 & 4.5 & 24.2 \\
\hline Biotite ........ & & 0.8 & 6.5 & 8.5 & 1.7 \\
\hline Serpentine ..... & 4. 4 & - & - & - & - \\
\hline Chlorite ........ & & ) 13 & 一 & - & 一 \\
\hline Epidote ........ & & \} 1.3 & - & - & - \\
\hline \multirow{3}{*}{ Others ......... } & 3.7 & & 2.3 & 1.0 & 1.0 \\
\hline & 0.2 & $\left.5.2^{\circ}\right)$ & 0.4 & 1.0 & 0.7 \\
\hline & 100.0 & |100.0 & $\mid 100.0$ & $\mid 100.0$ & $\mid 100.0$ \\
\hline
\end{tabular}

1) According to Kallio (1967)

2) "Amphibole»

3) Includes apatite $2.9 \%$ and »others» $2.3 \%$

The Fe-Ti oxides were separated from crushed and sieved material, $0.125-0.050 \mathrm{~mm}$ in diameter, utilizing heavy liquids (bromoform and Clerici solution), hand magnet and isodynamic separator. When separating ilmenite from magnetite, a heated Clerici solution with a specific gravity between those of magnetite and ilmenite (ca. 4.7) was used. Finally, impurities were handpicked under a binocular microscope. Polished powder sections were prepared from the final concentrates for the study of the exsolution textures and purity of the material.

\section{Textures of the Fe-Ti oxides}

The titaniferous magnetite from the Sorkka diabase consists mainly of Ti-bearing magnetite, which contains ilmenite lamellae parallel to the octahedral planes. High magnification and oil immersion often enable extremely small dark gray ulvite exsolution lamellae to be distinguished between the ilmenite lamellae. There are also intergrowths of larger, irregular shaped grains of homogenous Ti-bearing magnetite and ilmenite (Figs. 1 and 2). Intergrowths such as these are uniform at their outer margins, as if they were 


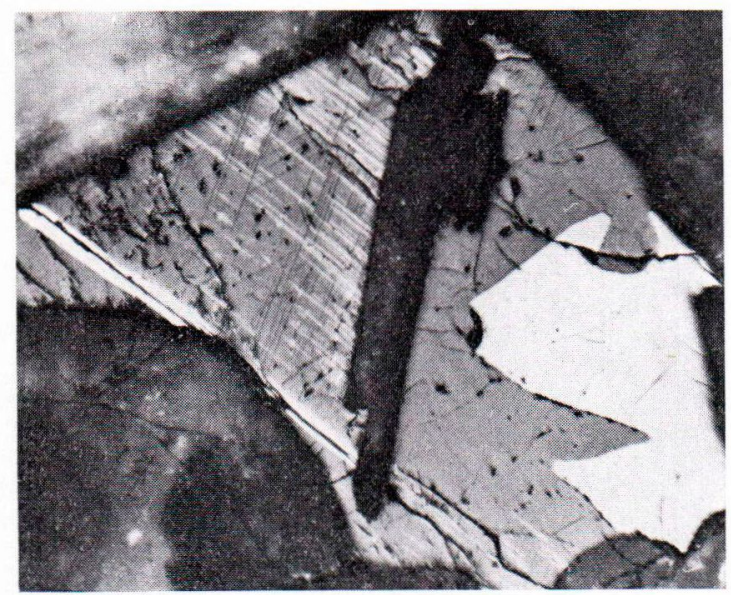

Fig. 1. Titaniferous magnetite from the Sorkka diabase. The magnetite is divided into two parts by a plagioclase lath (dark grey). On the left, the titaniferous magnetite contains ilmenite lamellae (lamellar exsolution). On the right, there is a large ilmenite grain (white) produced by granule exsolution. Polished section, crossed nicols, magn. $50 \times$. Photo, Erkki Halme.

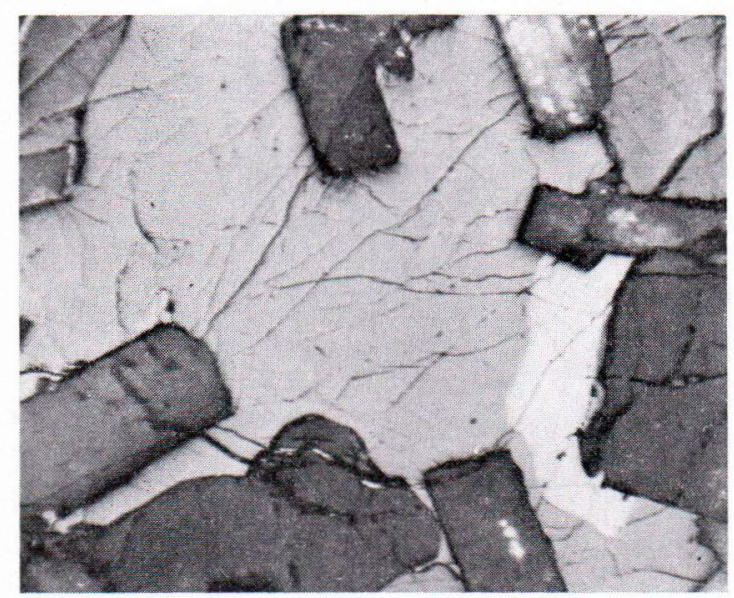

Fig. 2. Titaniferous magnetite from the Sorkka diabase. In the homogenous Ti-bearing magnetite there is a large ilmenite grain (white), indicating granule exsolution. Polished section, crossed nicols, magn. $50 \times$. Photo, Erkki Halme.

only one grain. The ilmenite grains tend to be located on the outer boundary of the intergrowths. There are no ilmenite lamellae near these ilmenite grains in the titaniferous magnetite, though lamellae may exist further away in the same grain (Fig. 1). Similarly, thin ilmenite lamellae do not exist near thick ilmenite lamellae. It was verified by electron microprobe(Dr. Jaakko Siivola) that the $\mathrm{TiO}_{2}$ content of the homogeneous titaniferous magnetite near these ilmenite grains is as high as or a little lower (about $20 \%$ $\mathrm{TiO}_{2}$ ) than in the magnetite between the ilmeninite lamellae. All these facts indicate that the ilmenite grains in magnetite are formed by "granule exsolution» through the oxidation of the ulvite component of the homogeneous singlephase mineral (Wright 1961, Buddington and Lindsley 1964, Vaasjoki and Puustinen 1966). In the Sorkka diabase, the generalization may be made that either granular or lamellar ilmenite oxidation-exsolution bodies but not both may occur in the same titaniferous magnet ${ }^{1}$ te grain or in the same part of a titaniferous magnetite grain (see Fig. 1). The granule and lamellar oxidationexsolution phenomena probably have been largely simultaneous. In addition to the ilmenite grains produced by the oxidation-exsolution, there are also discrete ilmenite grains which are interpreted as primary. Some magnetite grains are corroded and oxidized in a way similar to that described by Neuvonen (1965).

The titaniferous magnetite from the Mäntyharju gabbroanorthosite also contains granular ilmenite oxidation-exsolution bodies besides ilmenite lamellae. In addition, some small black spinel lamellae are visible in the magnetite. There are clearly several generations of ilmenite lamellae. There seem to be very thin ilmenite lamellae parallel to $\{100\}$ (Fig. 3) or $\{111\}$ between the coarse ilmenite lamellae parallel to $\{111\}$ of magnetite. The titaniferous magnetite grains have a mosaic texture owing to the fact that most of the thin ilmenite lamellae extinct in different areas of the same host magnetite crystal at different times but simultaneously in the same mosaic area, always parallel to one of the three $\{111\}$ planes of magnetite. With high magnification and oil immersion it can be detected that the »ilmenite lamellae» parallel to $\{100\}$ consist of magnetite and extremely small ilmenite lamellae oriented parallel to $\{111\}$ of the host magne- 


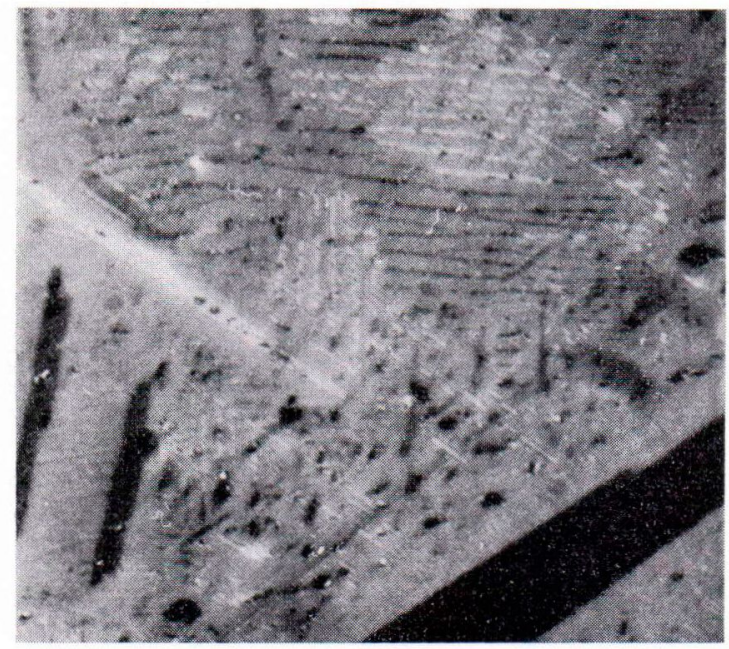

Fig. 3. Titaniferous magnetite from the Mäntyharju gabbroanorthosite. There are thin lamellae parallel to $\{100\}$ between the coarse ilmenite lamellae parallel to $\{111\}$. These thin lamellae consist of magnetite and extremely small ilmenite lamellae parallel to $\{111\}$. Polished section, crossed nicols, oil immersion, magn. $800 \times$ Photo, Erkki Halme.

tite (Fig. 3). These small ilmenite lamellae are clearly formed by the oxidation of ulvite lamellae $\left(3 \mathrm{Fe}_{2} \mathrm{TiO}_{4}+1 / 2 \mathrm{O}_{2}=3 \mathrm{FeTiO}_{3}+\mathrm{Fe}_{3} \mathrm{O}_{4}\right.$, Ramdohr 1953). Primary ulvite was not detected in the gabbroanorthosite.

The magnetite of the Mikkeli and Virtasalmi quartz diorites does not contain exsolution bodies. Also the ilmenites of the Sorkka diabase and Mäntyharju gabbroanorthosite are homogeneous, whereas ilmenites of the Mikkeli and Virtasalmi quartz diorites contain abundant lensoid hematite exsolution bodies.

\section{X-ray single-crystal studies}

Two titanifetous magnetite grains containing ilmenite lamellae were studied by X-ray technique using the precession method. The grains were detached from a polished section made from the titaniferous magnetite concentrate of the Sorkka diabase. One of these grains also contained some minute ulvite exsolution lamellae. Zero-level precession photographs about magnetite [100] and [110] axes were taken from both of the grains. The precession angle was $30^{\circ}$ and the radiation Zr-filtered Mo radiation.

The following crystallographic orientation law of ilmenite lamellae was obtained from the precession photographs in respect to their host magnetite:

$[0001]_{\mathrm{ilm}} / /[111]_{\text {magn }}$ whereat $12 \cdot \mathrm{d}^{*}{ }_{0001} \approx 4 \mathrm{~d}_{111}^{*}$, $[10 \overline{10}]_{\mathrm{ilm}} \perp[110]_{\mathrm{magn}}$, whereat $3 \cdot \mathrm{d}^{*}{ }_{01 \overline{1} 0} \approx 4 \mathrm{~d}_{110}^{*}$.

The orientation rules of magnetite-ilmenite intergrowths which led to the same law had been determined already very early on the basis of morphological studies of large crystals (Mügge 1903).

Diffuse reflections of ulvite were detectable in the precession photographs taken from one of the crystals. Ulvite is homoaxially intergrown with magnetite.

The unit cell dimensions of these minerals were calculated from the precession photographs. The film shrinkage was calibrated by a silicon standard. The calculations gave the following results:

$$
\begin{aligned}
& a_{\text {o magnetite }}=8.41 \pm 0.01 \AA \\
& a_{\text {o ulvite }}=8.50 \pm 0.02 \AA \\
& a_{\text {o ilmenite }}=5.09 \pm 0.01 \AA \\
& c_{\text {o ilmenite }}=14.09 \pm 0.02 \AA
\end{aligned}
$$

The exsolution bodies of the Virtasalmi ilmenite were identified as hematite also by singlecrystal studies. These homoetypic minerals are homoaxially intergrown.

\section{The chemical analyses}

The chemical analyses of the Fe-Ti oxides are presented in Tables 2 and 3. In order to apply the experimental data the analyses were recalculated to binary solid solutions magnetite-ulvite and ilmenite-hematite. Two alternative calcula- 
TABLE 2

Chemical analyses of magnetites. Anal. P. Ojanperä. Numbering of the specimens in the text (p. 14)

\begin{tabular}{|c|c|c|c|c|c|}
\hline & 1 & 2 & 3 & 4 & 5 \\
\hline $\mathrm{SiO}_{2} \ldots$. & 0.46 & 0.66 & 0.19 & 0.12 & 0.28 \\
\hline $\mathrm{TiO}_{2} \ldots$ & 21.05 & 10.76 & 1.38 & 1.01 & 0.78 \\
\hline $\mathrm{Al}_{2} \mathrm{O}_{3} \ldots$ & $2.65^{*}$ & 2.82 & $0.38 *$ & $0.28 *$ & $0.47 *$ \\
\hline $\mathrm{Fe}_{2} \mathrm{O}_{3} \ldots$ & 31.00 & 50.71 & 67.19 & 67.51 & 66.29 \\
\hline $\mathrm{FeO} \ldots \ldots$ & 41.98 & 33.27 & 30.32 & 30.18 & 30.50 \\
\hline $\mathrm{MnO} \ldots$ & 0.63 & 0.15 & 0.20 & 0.10 & 0.04 \\
\hline $\mathrm{MgO} \ldots$. & 1.56 & 0.08 & 0.10 & 0.06 & 0.24 \\
\hline $\mathrm{CaO} \ldots \ldots$ & 0.15 & 0.14 & 0.01 & 0.04 & 0.02 \\
\hline $\mathrm{V}_{2} \mathrm{O}_{3} \ldots$ & $0.47 *$ & $0.59 *$ & $0.35^{*}$ & $0.38^{*}$ & $0.66^{*}$ \\
\hline $\mathrm{Cr}_{2} \mathrm{O}_{3} \ldots$ & $0.23 *$ & $0.07 *$ & $0.06^{*}$ & $0.18 *$ & $0.07 *$ \\
\hline Sum & 100.18 & 99.25 & 100.18 & 99.86 & 99.35 \\
\hline & $0.035^{*}$ & $0.007 *$ & $0.005 *$ & $0.007 *$ & $0.018 *$ \\
\hline Co .. & $0.026 *$ & $0.007 *$ & $0.006 *$ & $0.006 *$ & $0.007 *$ \\
\hline $\mathrm{Cu} \ldots \ldots$ & $0.006 *$ & $0.002 *$ & $0.003 *$ & $0.004 *$ & $0.005^{*}$ \\
\hline a) $\mathrm{Fe}_{3} \mathrm{O}_{4}$. & 36.0 & 66.4 & 96.0 & 97.0 & 97.7 \\
\hline $\mathrm{Fe}_{2} \mathrm{TiO}_{4}$ & 64.0 & 33.4 & 4. 0 & 3.0 & 2.3 \\
\hline b) $\mathrm{Fe}_{3} \mathrm{O}_{4}$ & 36.1 & 67.2 & 96.0 & 97.0 & 97.7 \\
\hline $\mathrm{Fe}_{2} \mathrm{TiO}_{4}$ & 63.9 & 32.8 & 4. 0 & 3.0 & 2.3 \\
\hline
\end{tabular}

* Spectrochemical determination by Arvo Löfgren

TABLE 3

Chemical analyses of ilmenites and the estimated equilibration temperatures and oxygen fugacities of coexisting magnetite and ilmenite. Anal. P. Ojanperä.

Numbering of the specimens the same as on p. 14

\begin{tabular}{|c|c|c|c|c|c|}
\hline & 1 & 2 & 3 & 4 & 5 \\
\hline $\mathrm{SiO}_{2} \ldots \ldots$ & 0.59 & 0.36 & 0.16 & 0.06 & 0.12 \\
\hline $\mathrm{TiO}_{2} \ldots$ & 50.66 & 50.44 & 48.34 & 48.14 & 44.29 \\
\hline $\mathrm{Al}_{2} \mathrm{O}_{3} \ldots$ & $0.21 *$ & 0.30 & $0.38 *$ & $0.21 *$ & $0.19 *$ \\
\hline $\mathrm{Fe}_{2} \mathrm{O}_{3} \ldots$ & 5.50 & 6.89 & 9.42 & 10.54 & 16.50 \\
\hline $\mathrm{FeO} \ldots \ldots$ & 39.34 & 40.45 & 34.06 & 37.84 & 37.69 \\
\hline $\mathrm{MnO} \ldots$ & 0.60 & 0.71 & 6.49 & 2.43 & 0.57 \\
\hline $\mathrm{MgO} \ldots$. & 2.45 & 0.03 & 0.49 & 0.23 & 0.57 \\
\hline $\mathrm{CaO} \ldots$. & 0.29 & 0.19 & 0.18 & 0.27 & 0.17 \\
\hline $\mathrm{V}_{2} \mathrm{O}_{3} \quad \ldots$ & $0.09 *$ & $0.01 *$ & $0.07 *$ & $0.06 *$ & $0.21 *$ \\
\hline $\mathrm{Cr}_{2} \mathrm{O}_{3} \ldots$ & $0.009 *$ & $0.01 *$ & $0.20 *$ & $0.03 *$ & $0.03 *$ \\
\hline Sum... & 99.739 & 99.39 & 99.79 & 99.81 & 100.34 \\
\hline $\mathrm{Ni}$ & $0.00 *$ & $0.001 *$ & $0.012 *$ & $0.005 *$ & $0.005^{*}$ \\
\hline Co & $0.013 *$ & $0.006 *$ & $0.007 *$ & $0.001 *$ & $0.001 *$ \\
\hline $\mathrm{Cu} \ldots .$. & $0.01 *$ & $0.008 *$ & $0.022 *$ & $0.017^{*}$ & $0.016 *$ \\
\hline a) $\mathrm{FeTiO}_{3}$. & 95.6 & 97.6 & 93.1 & 91.7 & 84.0 \\
\hline $\mathrm{Fe}_{2} \mathrm{O}_{3}$ & 4.4 & 2.4 & 6.9 & 8.3 & 16.0 \\
\hline b) $\mathrm{FeTiO}_{3}$ & 94.1 & 92.9 & 90.6 & 88.9 & 83.5 \\
\hline $\mathrm{Fe}_{2} \mathrm{O}_{3}$ & 5.9 & 7.1 & 9.4 & 11.1 & 16.5 \\
\hline a) $\mathrm{T}^{\circ} \mathrm{C}$ & 910 & $\sim 670$ & $\leq 550$ & $\leq 550$ & $\leq 550$ \\
\hline$f \mathrm{O}_{2} \cdots$ & $10-13 *^{0}$ & $10-19.5$ & $\leq 10-19$ & $\leq 10-19$ & $\leq 10-19$ \\
\hline b) $\mathrm{T}^{\circ} \mathrm{C} \ldots$ & 960 & 760 & $\leq 550$ & $\leq 550$ & $\leq 550$ \\
\hline & $\mid 0-11 \cdot 9$ & $10-15.5$ & $\leq 10-19$ & $\leq 10^{19}$ & $\leq 10-19$ \\
\hline
\end{tabular}

* Spectrochemical determination by Arvo Löfgren tion methods were used, both of which are essentially similar to those presented in Buddington and Lindsley (1964):

a) The amount of $\mathrm{SiO}_{2}$ is regarded to be derived from silicate impurities. When calculating the Fe-Ti oxides of diabase and gabbroanorthosite, the analysed oxides $\left(\mathrm{CaO}, \mathrm{Al}_{2} \mathrm{O}_{3}, \mathrm{SiO}_{2}\right)$ corresponding to plagioclase $\mathrm{An}_{50} \mathrm{Ab}_{50}$ are first discarded. The remaining $\mathrm{SiO}_{2}$ is combined with an equal amount of $\mathrm{RO}$ to form pyroxene and then discarded. The $\mathrm{SiO}_{2}$ of the $\mathrm{Fe}$-Ti oxide analyses of the quartz diorites is discarded as quartz. Then the minor amounts of oxides RO and $\mathrm{R}_{2} \mathrm{O}_{3}$ are discarded according to the rules given in Buddington and Lindsley (op. cit.). The remaining, slightly changed amounts of $\mathrm{FeO}$, $\mathrm{Fe}_{2} \mathrm{O}_{3}$ and $\mathrm{TiO}_{2}$ are recalculated to express the molecular percentage of the ulvite in magnetite and the hematite in ilmenite.

b) The named solid solutions are calculated directly from the original values of $\mathrm{FeO}, \mathrm{Fe}_{2} \mathrm{O}_{3}$ and $\mathrm{TiO}_{2}$. In calculating the ilmenite composition, the amount of $\mathrm{TiO}_{2}$ exceeding $\mathrm{FeO}$ is discarded.

The ulvite percentages of the magnetites do not change much with the different methods of calculation, whereas the hematite contents of the ilmenites vary considerably. The hematite contents calculated directly from $\mathrm{Fe}_{2} \mathrm{O}_{3}$ contents of the ilmenite analyses may be too high owing to the oxidation of the ilmenite $\left(2 \mathrm{FeTiO}_{3}+1 / 2 \mathrm{O}_{2}\right.$ $=\mathrm{Fe}_{2} \mathrm{O}_{3}+2 \mathrm{TiO}_{2}$ ). On the other hand, the hematite contents based on complete ilmenite analyses can be taken as minima owing to the possible equilibration of the Fe-Ti oxides during cooling (Anderson 1968). Still other calculation methods are presented in Carmichael (1967 a) and Anderson (op. cit.). Because it is not yet clear which one of the calculation methods gives the most correct results ( $c f$. e.g. Speidel 1970, p. 352), the calculation procedures presented originally by Buddington and Lindsley are used in this paper. 


\section{Results}

Numerical values of equilibration temperatures and oxygen fugacities were obtained only for the Fe-Ti oxides of the Sorkka diabase and Mäntyharju gabbroanorthosite. Even with these rocks, the values received by the different calculation methods are different.

Obviously the temperatures obtained for the Sorkka diabase and particularly for the Mäntyharju gabbroanorthosite by calculation method a) are somewhat too low compared with the initial crystallization temperature, owing mainly to the granule oxidation-exsolution of ilmenite. When crushed for mineral separation, it is probable that such »exsolved» ilmenite grains fall into the ilmenite concentrate during separation, though they should belong to the titaniferous magnetite concentrate. In order to estimate the effect of granule oxidation-exsolution on the temperature and oxygen fugacity, a small amount of titaniferous magnetite grains, $1.0-0.2 \mathrm{~mm}$ in diameter, was separated from the Sorkka diabase and analysed for titanium. The analysis gave $24.60 \% \mathrm{TiO}_{2}$. This corresponds to a composition of $69.4 \% \mathrm{Fe}_{2} \mathrm{TiO}_{4}$ and $30.6 \% \mathrm{Fe}_{3} \mathrm{O}_{4}$. The crystallization (equilibration) temperatures and oxygen fugacities received for this titaniferous magnetite on the basis of ilmenite compositions a) and b) of column 1 , Table 3 , are a) $970^{\circ} \mathrm{C}$ and $10^{-12} \cdot{ }^{0}$ atm., and b) $1000^{\circ} \mathrm{C}$ and $10^{-11} \cdot{ }^{4}$ atm., respectively. These temperatures are 60 $-40^{\circ}$ higher than those of Table 3. In the case of the Mäntyharju gabbroanorthosite, the effect of granule exsolution is probably much higher.

Eskola (1925) made experimental studies concerning the crystallization temperature of the »Satakunta olivine diabase» in the Geophysical Laboratory of the Carnegie Institute. The Sorkka diabase is one of the Satakunta diabase dikes. At a pressure of $1 \mathrm{~atm}$. the crystallization temperature was about $1200-1050^{\circ} \mathrm{C}$. At 2800 atm. pressure and with a couple per cent water dissolved into the melt, the crystallization tempera- ture dropped to $850-800^{\circ} \mathrm{C}$. The pressure of $2800 \mathrm{~atm}$. approximately corresponds to a depth of $10 \mathrm{~km}$ in the earth's crust. The true crystallization temperature of the Satakunta diabase is apparently between the two temperature ranges obtained experimentally by Eskola.

No exact numerical values were obtained for the equilibration temperature and oxygen fugacity of the Fe-Ti oxide pairs of the Mikkeli and Virtasalmi quartz diorites. The compositions of these oxides fall outside the range covered by the experimental data. From the curves it can be deduced that these oxides equilibrated at temperatures $\leq 550^{\circ} \mathrm{C}$ (possibly about $500^{\circ} \mathrm{C}$ ) and at oxygen fugacities $\leq 10^{-19}$ atm. In any case, the equilibration temperatures are not magmatic and they are still somewhat lower than those recorded by Buddington and Lindsley (1964) for the hornblende granite gneisses of the Adirondac area. Refering to Winkler (1967), Hyvärinen (1968, p. 43) suggested that the acid schists of the Virtasalmi area metamorphosed at a temperature of $650 \pm 30^{\circ} \mathrm{C}$ and under a pressure of $5000 \pm 1000$ bars. He did not reveal the P-T conditions of metamorphism of the quartz diorites.

\section{Distribution of $\mathrm{MnO}$ between Fe-Ti oxides}

Buddington and Lindsley (1964) and Dasgupta (1970) showed that there is a correlation between the crystallization temperature and distribution of manganese between coexisting magnetite and ilmenite. Buddington and Lindsley's graph showing the distribution lines for the three different types of rocks is reproduced in Fig. 4. The lines represent the averages of different rocks and scattering is comparatively high. If the magnetite contains less than $0.13 \% \mathrm{MnO}$, the distribution ratios of metamorphic rocks and gabbros and associated ores overlap. The temperatures given are taken from the text of Buddington and Lindsley and they are estimated from the coexisting Fe-Ti oxides. The points representing the dis- 


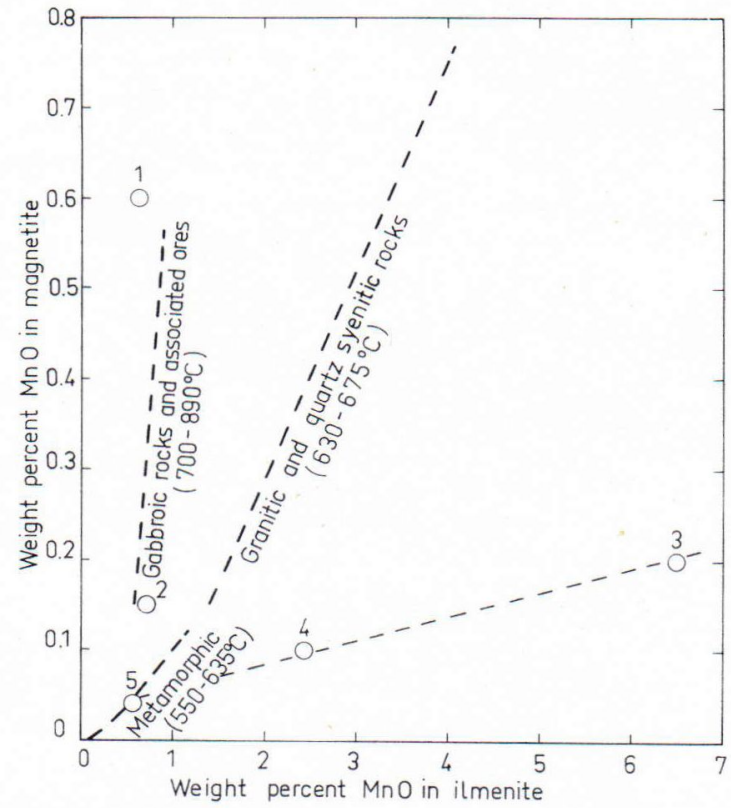

Fig. 4. Distribution of manganese between coexisting magnetite and ilmenite. The thick broken lines are quoted from Buddington and Lindsley (1964, p. 353). The numbered points refer to the Fe-Ti oxides of the present study (Tables 2 and 3 ).

tribution of $\mathrm{MnO}$ between the Fe-Ti oxide pairs of the present study are added to the graph. The ratio $\mathrm{MnO}$ in ilmenite to $\mathrm{MnO}$ in magnetite is a little lower for the Sorkka diabase than the ratios on the average distribution line of the gabbroic rocks and associated ores. The distribution ratio of $\mathrm{MnO}$ between the Fe-Ti oxides of the Mäntyharju gabbroanorthosite falls almost on the line. The distribution ratios of the Mikkeli and Virtasalmi (Litmanen) quartz diorites are quite different from those presented in the graph of Buddington and Lindsley. The distribution ratios of the three quartz diorites fall almost exactly on a straight line. The equilibration temperatures of the $\mathrm{Fe}-\mathrm{Ti}$ oxides of these rocks are $\leq 550^{\circ} \mathrm{C}$, or clearly lower than those of the »metamorphic» (high grade amphibolite and granulite facies) rocks of Buddington and Lindsley.

\section{Conclusions}

Analysed pairs of coexisting magnetite and ilmenite are used with obvious success as a geothermometer and oxygen barometer for numerous rocks (e.g. Buddington and Lindsley 1964 , Carmichael $1967 \mathrm{a}$ and b). The method has some limitations which have been throughly discussed by Buddington et al. 1955, Buddington and Lindsley (op. cit.) and Anderson (1968). Obviously, the most considerable restriction is that caused by the granule oxidation-exsolution of ilmenite, which is common especially in gabbroic rocks. This limitation could perhaps be avoided by a combination of microprobe and planimetric analyses. As pointed out by Anderson (op. cit.), the hematite content observed for ilmenite may be too low owing to the equilibration of $\mathrm{Fe}-\mathrm{Ti}$ oxides during cooling. Owing to these limitations, the observed temperatures may be regarded as minima. Also, the phase relations in complicated chemical systems may be somewhat different from those of the system $\mathrm{FeO}-\mathrm{Fe}_{2} \mathrm{O}_{3}$ $-\mathrm{TiO}_{2}$. The effects of minor constituents are not yet clear. An important restriction is caused by the fact that experimental studies do not as yet cover the whole stability field of natural Fe-Ti oxides. Coexisting Fe-Ti oxide pairs, which are either very rich or very poor in both ulvite and ilmenite, do not give unique results because the temperature-oxygen fugacity curves are nearly parallel. It is also required that the $\mathrm{Fe}-\mathrm{Ti}$ oxides have formed in equilibrium with each other during the crystallization (or recrystallization) of the host rock.

Some if not all of the named restrictions interfere when estimating the crystallization temperatures and oxygen fugacities of the Fe-Ti oxides of the present study. Numerical values of $\mathrm{T}$ and $\mathrm{fO}_{2}$ were only obtained for the $\mathrm{Fe}-\mathrm{Ti}$ oxides of the Sorkka diabase and the Mäntyharju gabbroanorthosite. Even in the case of these rocks, the temperatures obtained by the calculations based on the total analyses must be regarded as minima relative to the temperatures 
of initial crystallization, owing to the granule oxidation-exsolution and possible equilibration during cooling. Apparently the temperatures and oxygen fugacities obtained on the basis of the ilmenite composition and the $\mathrm{TiO}_{2}$ content of the $0.2-1.0 \mathrm{~mm}$ titaniferous magnetite fraction (p. 18) for the Fe-Ti oxides of the Sorkka diabase are the most accurate. In the case of the quartz diorites, too much extrapolation is needed to give accurate results.
Acknowledgements - Messrs Erkki Ristimaa and Jouko Pääkkönen gave assistance in the mineral separation. Mr. Arvo Löfgren, Mag. Phil., carried out the spectrochemical analyses. The gabbroanothosite sample (No. A-118) was placed at the authors' disposal by Dr. Olavi Kouvo. Dr. Siivola made the microprobe determinations and read the manuscript critically. Mr. Erkki Halme took the photographs. The writers express their sincere thanks to all these gentlemen.

\section{REFERENCES}

Abdullah, M. I. and Atherton M. P. (1964) The thermometric significance of magnetite in low grade metamorphic rocks. Amer. Journ. Sci. 262, 904-917.

Anderson, A. T. (1968) Oxidation of the La Blache lake titaniferous magnetite deposit. Quebec. Journ. Geol. $76,528-547$.

Buddington, H. F., Fahey, J. and Vlisidis, A. (1955) Thermometric and petrogenetic significance of titaniferous magnetite. Amer. Journ. Sci. 253, 497-532.

- and Lindsley, D. H. (1964) Iron-titanium oxide minerals and synthetic equivalents. Journ. Petrol. 5, $310-357$.

Carmichael, I. S. E. (1967 a) The iron titanium oxides of salic volcanic rocks and their associated ferromagnesian silicates. Contrib. Mineral. Petrol. 14, $36-64$.

- (1967 b) The mineralogy of Thingmuli, a Tertiary volcano in eastern Iceland. Amer. Mineral. 52, 1815 1841.

Dasgupta, H. C. (1970) Influence of temperature and oxygen fugacity on the fractionation of manganese between coexisting titaniferous magnetite and ilmenite. Journ. Geol. 78, 243-249.

Eskola, P. (1925) Ala-Satakunnan kallioperusta. Satakunta. Kotiseutututkimuksia V 297-335. Verner Söderström Oy, Porvoo 1925.

Herer, K. (1956) Thermometric and petrogenetic significance of titaniferous magnetite-discussion. Amer. Journ. Sci. 254, 506-510.

HYVÄRINEN, L. (1968) On the geology of copper ore field in the Virtasalmi area, eastern Finland. Bull. Comm. géol. Finlande 240.

Kaнma, A. (1951) On contact phenomena of the Satakunta diabase. Bull Comm. géol. Finlande 152.
Kallio, P. (1967) Perrierite from Mäntyharju, Finland. Mineralogical communication. C. R. Soc. géol. Finlande $39,41-43$.

LAItAkARI, A. (1928) Palingenese am Kontakt des Postjotnischen Olivindiabases. Fennia 50, No. 35.

Lindsley, D. H. (1962) Investigations in the system $\mathrm{FeO}-\mathrm{Fe}_{2} \mathrm{O}_{3}-\mathrm{TiO}_{2}$. Carnegie Inst. Wash. Yearb. 61, $100-106$.

- (1963) Equilibrium relations of coexisting pairs of Fe-Ti-oxides. Ibid. 62, 60-66.

Marmo, V. (1959) On the $\mathrm{TiO}_{2}$-content of magnetites as a petrogenetic hint. Amer. Journ. Sci. 257, 144-149.

MüGGE, O. Die regelmässigen Verwachsungen von Mineralen verschiedenen Art. Neues Jahrbuch Mineral., Geol. Paleontol. Beilage-Band 16, 335-475.

Neuvonen, K. J. (1965) Paleomagnetism of the dike systems in Finland I. Remanent magnetization of Jotnian dolerites in southwestern Finland. C. R. Soc. géol. Finlande 37, 153-168.

Ramdohr, P. (1953) Ulvöspinel and its significance in titaniferous iron ores. Econ. Geol. 48, 677-688.

Savolahtr, A. (1956) The Ahvenisto massif in Finland. Bull. Comm. géol. Finlande 174.

- (1966) The differentiation of gabbroanorthosite intrusions and the formation of anothosites. C. R. Soc. géol. Finlande 38, pp. 173-197.

SpIedel, D. H. (1970) Effect of magnesium on the irontitanium oxides. Amer. Journ. Sci. 268, 341-353.

Winkler, H. G. F. (1967) Die Genese der metamorphen Gesteine. Springer-Verlag, Berlin.

Manuscript received, April 7, 1971. 